
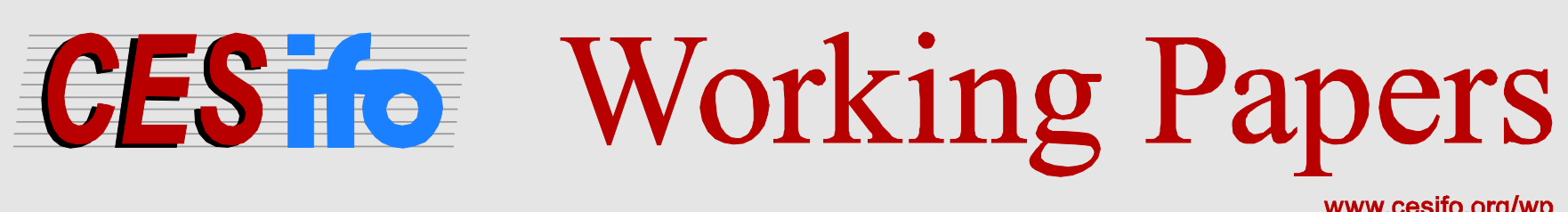

www.cesifo.org/wp

\title{
The Democratization of Rent Seeking in Greece
}

\author{
Thomas Moutos \\ Lambros Pechlivanos
}

CESIFO WORKING PAPER NO. 4331

CATEgory 2: Public CHOICE

JULY 2013

An electronic version of the paper may be downloaded

- from the SSRN website:

- from the RePEc website:

- from the CESifo website:

WWw.SSRN.com

www.RePEc.org

www.CESifo-group.org/wp

\section{CESifo}




\title{
The Democratization of Rent Seeking in Greece
}

\begin{abstract}
We describe the evolution of the power struggle in Greece among key economic and political stakeholders, who have tried, via strategic positioning and rent-seeking activities, to influence economic policy outcomes during the postwar decades. We split the postwar decades in three periods: the catching-up period, the overt populism period of 1973-1993, and the 1993-2008 of stealth populism. In each period, we identify the important players to see how they managed to forge a sustainable wining coalition, and to understand how they shaped policies. The three periods vary substantially in terms of the inherent degree of economic inefficiency they brought about; the first one was characterized by a concentration of rent-seeking mainly among the economic and political elite, whereas the middle period exemplifies the "democratization" of rent-seeking. The middle period's proliferation of rent seeking received some legitimacy by large segments of the population due to widespread, and often ideological, perceptions of long-lasting unfairness in the distribution of economic and political power. The covert populism of the last period used an unsustainable expansion of foreign borrowing to allow for an intensification of rent seeking while providing a semblance of fiscal rectitude.
\end{abstract}

JEL-Code: P160, N140, H110.

Keywords: rent seeking, democratization, populism, political economy, power struggle, history, Greece.

\author{
Thomas Moutos \\ Department of International and \\ European Economic Studies \\ Athens University of Economics and \\ Business (AUEB) \\ Patission 76 \\ Greece - Athens 10434 \\ tmoutos@aueb.gr
}

\author{
Lambros Pechlivanos \\ Department of International and European \\ Economic Studies \\ Athens University of Economics and \\ Business (AUEB) \\ Patission 76 \\ Greece-Athens 10434 \\ lpech@aueb.gr
}

Without implicating, we wish to thank Spyros Vassilakis for helpful comments and suggestions. 


\section{Introduction}

This paper presents a brief synopsis of the economic history in post-second world war Greece, within a political economy framework. This is done by attempting to explain the evolution of the power struggle among different stakeholders, who try, via strategic positioning and rent-seeking activities, to influence economic policy outcomes. In each period, we identify the important players to see how they manage to forge a sustainable wining coalition, and to understand the efficiency properties of the enacted policies. ${ }^{1}$

Although, it is not difficult to find anecdotes in which interested parties directly influence political decisions via sheer power or monetary transfers, we opt to focus on activities that shape the evolution of public institutions, which are necessary to propagate the power of established interest groups or to nurture the creation of new players. ${ }^{2}$

In the spirit of Stigler (1971) and Peltzman (1976), we try to understand how interest groups attempt to become more effective in exercising their power by guarding against free riding behavior, through the implantation of protective rules. We then offer a description of different winning coalitions, across time, and explain how their characteristics (broadness, composition etc) lead to the adoption of policies that give rise to different degrees of inefficiency. Conditions which are external to the analysis, such as scarcity of resources or soft budget constraints due to access to outside financing, are also used to understand different societal tolerance to inefficient public policies.

Nonetheless, even when external conditions are conducive to inefficient outcomes one has to question the reasons for which a more efficient outcome does not arise. This is essentially an argument in the tradition of a Coasian - Williamsonian analysis of the evolution of government structures. ${ }^{3}$ To address this question we take into account the ideological background within which public discourse on economic policy developed in Greece. Fueled by ancestral feelings of economic inequality and social stratification (i.e., deep-rooted perceptions against the illegitimacy of the existing social and economic order), which got exploited in the public arena, a cynical approach has evolved according to which public policy looks more like a zero-sum game, where the redistributive effects play the major role while efficiency reasoning retreats to obscurity. ${ }^{4}$

\footnotetext{
${ }^{1}$ We abstain from any quantitative assessment of rent seeking in Greece. Angelopoulos et al (2009) provide estimates of the social costs of rent seeking. Their model-based calculations indicate that Greece exhibits the highest rent extraction and rent seeking among EU countries, with about 53\% of tax revenue extracted by rent seekers. Our discussion of rent seeking covers also acts of omission or commission by government officials (e.g., regulation) which do not directly impinge on tax revenue.

${ }^{2}$ We focus on key players since we regard it is an oxymoron to assume that the competitive process is distorted by the creation of rents, and yet the process of rent creation is subject to perfectly competitive markets for rent-capture.

${ }^{3}$ For example, see Coase (1937) and Williamson $(1985,1996)$

${ }^{4}$ Piketty (1995) argues that perceptions about the unfairness of social and economic outcomes are significant determinants of voters' preferences over redistributive fiscal policies. Moreover, Passarelli and Tabellini (2013) provide a theoretical model in which (privately) costly participation in political unrest (which has been a common occurrence in Greece) may be the result of emotions-motivated
} 
We split the post-WWII era in three periods: a) the 1944-1973 period of rapid growth, b) the 1973-1993 period of overt populism and stagnation, and c) the 1993-2008 period of stealth populism, during which intended declarations of "modernization" and "state-rebuilding" coincided with excessive private-sector borrowing and huge increase of the country's (i.e., private-cum-public sector) net indebtedness to the rest of the world.

The first period is characterized by a closely knit group of movers and shakers (that we will be calling "the elite") whose main goal was to propagate and enhance on the ante-bellum economic order. Their grip on the political arena was mainly based on personal relationships with politicians, whose power in turn was based on traditional patron-clientele relations, sometimes still attributed to kinship or local origin. To fabricate social cohesion and galvanize a winning coalition, the corporatist system instituted in the 1930's was kept intact, bringing thus valuable political support from constituents such as professionals and other service sector self-employed. Given the abysmal state of the Greek economy at the end of WWII, the goal of the economic elite was to instigate rapid growth policies, and to direct resources to industry, while at the same time keeping its oligopolistic structure. The main strife between the economic elite and the foreign aid donors was the allocation of funds towards the different sectors of the economy and the control of the distributive mechanisms. At bottom, the scarcity of resources and some degree of institutional autonomy of bureaucracy granted by the foreign intervention prevented the adoption of grossly inefficient policies.

The beginning of the second period coincides with the establishment of the Third Greek Republic. Demands for greater political and economic participation grew strong and got universal acceptance. As a result, a mass of new players (the "unprivileged", as Andreas Papandreou called them) entered in the political arena requesting a larger share of the social surplus. The main vehicle through which their demands were voiced was the creation of a party machine (PASOK) that altered completely the way through which politics could redistribute resources. Now, the ruling party had the de facto monopoly power over the allocation of resources and became the conduit through which demands were met. Non members were effectively foreclosed. The prime goal of party cadres was the perpetuation of their political power. Given that they understood themselves as redistribution facilitators economic efficiency considerations were ignored. Finally, intra-party competition nurtured a race to the bottom in the sense that different party cadres were trying to ensure that their constituents were getting the better deal. The results were disastrous as public debt accumulated, growth stalled, and the unemployment rate tripled.

The event that introduced the third period was the EMU-accession effort. This effort appeared - on the surface at least - to tame the ability of the political machine to cater to its constituents, as economic policy had now to focus on that goal. As a result the rhetoric in support of overt populist policies was retracted. Somehow, though, this successful bid brought the seeds of the restoration of the previous agenda. Eurozone membership allowed for the first time the Greek economy to have low cost access to finance from the

perceptions of unfairness. Importantly, they show how such political protests can affect public policy even when the policymaker is benevolent. 
international markets. This was game changer, as party cadres understood this as a tap to unlimited funding, whose cost would be pushed to future generations. As a result, the raid on public coffers intensified again, the private sector appeared happy with the newly-found opportunities for (foreign) credit-driven growth, and the Greek economy found itself heavily indebted to the rest of the world in the wake of the global financial crisis.

\section{Antecedents of the post-WWII economic order}

By the second decade of the twentieth century it was becoming evident to perceptive Greek politicians that "...the bourgeois state must realize that the danger posed by the lowerclasses in the twentieth century can be thwarted only by making sure that the just demands of the workers are swiftly met.." ${ }^{5}$ The increasing awareness of mainstream decision makers that this could well be a necessary action if liberal democracy was to survive, led to the signing by Greece in October 1919 of the six International Labour Conventions, which dealt with hours of work in industry, unemployment, maternity protection, night work for women, minimum age and night work for young persons in industry. ${ }^{6}$ The continuing social and economic pressures of the interwar period culminated with the Parliament's decision (Law 5733/1932) to establish the Social Insurance Foundation (IKA) in 1932 ; however the government was toppled and implementation of the decision was delayed until 1937, a year after the 1936 self-coup that solidified loannis Metaxas's rise to power. ${ }^{8}$

Among the alleged intentions of Metaxas' regime (1936-1941) was the abandonment of the existing mercantile/capitalist system and its replacement with a corporatist economic one, in order to promote the national interest. According to Clogg (1987), although the regime had "superficial trappings of Fascism" and Metaxas did not disguise his admiration for Nazism and Fascism, it is more correctly categorized as paternalist-authoritarian rather than fascist. Trade-unionism came under direct state control and, in parallel, state intervention in the regulation of labour relations widened. Metaxas's avowed aim was to foster "social and national solidarity" through rejection of individualism and class struggle. It consisted of a scheme for the gradual organization of all "productive classes" into cooperatives, through a horizontal (according to branches of production), rather than vertical (according to social

\footnotetext{
${ }^{5}$ This is our brief summary of what Dertilis (1985) quotes from one of Eleftherios Venizelos's (who was the pre-eminent Greek politician of the first half of the twentieth century) addresses to the Greek Parliament in 1911. Venizelos, a century ago, also expressed clearly what appears to be a perennial problem of Greek political economy: "Before the revolution, it was those connected with the expenditure column of (those feeding on) the budget that mainly governed Greece. Now, its fortunes are mainly in the hands of those who feed the budget's revenue column".

${ }^{6}$ These were the result of the first International Labour Conference in Washington, which was organized by the newly-formed International Labour Office. Among the stipulations of this conference was the eight-hour working day; Greece was allowed to implement gradually this regulation, and by the 1930s the eight-hour day was widely observed.

${ }^{7}$ Both the Confederation of Greek Industrialists (SEV) and the Banks' Union had made their objections to the law known to Prime Minister Venizelos (Liakos, 1993).

${ }^{8}$ By the time Law $5733 / 1932$ was implemented, it was subjected to significant amendments which weakened IKA's scope and curtailed the means available to it in order to become an effective social insurance organization. This development went in tandem with the establishment of many supplementary social insurance funds, whose number kept growing until the dawn of the twentiethfirst century.
} 
class), syndicalist organization. Instead of the atomistic (or egotistical) system of interest representation of liberal democracy, Metaxas's regime aim was to generate a system of interest representation in which the constituent units are organized into a limited number of singular, compulsory, noncompetitive, hierarchically ordered and functionally differentiated categories, recognized or licensed (if not created) by the state and granted a deliberate representational monopoly in exchange for observing certain "guidelines" on their selection of leaders and articulation of demands (Schmitter, 1974). It appears that the implicit goal of the regime was to use corporatism as a process for both the repression and co-optation of the labour movement and various interest groups. ${ }^{9}$

The economic performance of Metaxas's reign was not impressive. According to Maddison (2010) from 1936 to 1940 (Greece did not enter WWII until late in 1940), per capita GDP (in real terms) declined by $9 \%$ in Greece, whereas it rose by $10 \%$ on average among 12 advanced Western European countries. Yet, the regime's influence on subsequent economic developments was impressive as its model of corporatism (albeit under different guises) has retained its influence well into the 21 st century.

\section{Greece on Life-Support: $1944-1953$}

By the end of the Second World War the Greek economy was in ruins. In 1945, GDP was about $36 \%$ of its pre-war level. ${ }^{10}$ Hyperinflation had essentially demonetized the economy that had been reduced to little more than barter. Demand for cash was practically nonexistent. Real money balances were $5 \%$ of its pre-war level (Makinen, 1986). Even, in 1946 , the sum of all categories of bank deposits, in real terms, amounted to $4.3 \%$ of the 1938 level. ${ }^{11}$ At the same time, demand for gold sovereigns was booming, as gold hoarding became endemic. Big-ticket-item transactions were performed solely in gold sovereigns.

Among the first legislative initiatives of the post-liberation government was the "Currency Arrangement Law" (Law 18/10.11.1944) according to which the "new drachma" was introduced and all pre-existing contractual obligations, regardless of their denomination (gold or foreign currency), were converted into "old drachmas" at official exchange rates, and then converted again into "new drachmas." ${ }^{12}$ As a result, pre-war debt was essentially

\footnotetext{
${ }^{9}$ Some of the "carrot-and-stick" measures of the Metaxas regime are the "closure" to outsiders of many professions and the granting of "employment permits" to "nationally minded" persons, state control of syndicalism, restrictions on firing workers without the government's approval, the legislation of the minimum wage, and legislation rendering all strike activity illegal.

${ }^{10}$ The drop in Greek GDP was larger than that experienced by any other country - including Germany, Japan, and the USSR (Maddison, 2010). It was only in 1953 that Greece managed to surpass the level of GDP per capita it had achieved three decades earlier (in 1924).

${ }^{11}$ Actually, if one excludes the mandatory deposits of various semi-public legal entities, it becomes apparent that there was a complete break-down of the banking sector. (Pagoulatos, 2006).

${ }^{12}$ Each "new drachma" was worth 50 billion "old drachmas".
} 
forgiven, offering a clean slate to households and, more importantly, to firms that survived the occupation period. ${ }^{13}$

In addition, because there was a wide-spread popular resentment that an important group of well-connected individuals and firms collaborated with the occupying forces, a series of legislative initiatives were undertaken to partially undo such wealth redistribution that allegedly took place during the occupation, but also to stave off popular discontent. Law 182/1945 introduced punitive taxation on "financial enrichment" during occupation, and Laws 116/1946 and 1323/1949 allowed for the annulment of most real estate transfers that took place during that period.

However, it is widely believed that these laws were grossly inadequate in addressing popular concerns about collaborators' unethical enrichment, and that a group of collaborators and black-marketers ascended to the ruling class and managed to further gain from their involvement in the Marshall Plan (Kofas, 1989). These beliefs, and subsequent political developments until 1973, certainly helped to solidify the widespread perception about the unfairness of capitalism in Greece, and fostered and solidified the latent demands for extensive regulation and redistribution which surfaced in full force after 1973.

Intentionally or not, these policies helped to preserve to a large extent the pre-war economic status quo. Firms and industrialists that succeeded in surviving the war found themselves in relatively good terms. One trend that deserves to be noted is that during the first half of the occupation the banking sector became increasingly intertwined with industry as commercial banks (and by that we essentially mean the National Bank of Greece (NBG) that was by all means a monopoly) were acquiring blockholdings in various firms by converting non-performing loans to equity. ${ }^{14}$

The first post-liberation governments were rather unsuccessful in addressing hyperinflation. Three different stabilization programs were initiated, but it was only in 1946 that inflation was finally tamed, possibly due to a greater British involvement. As a result, monetary policy throughout that period was solely focused in fighting inflation. This restrictive monetary policy was further entrenched with the institution of the Currency Committee in 1946, which effectively was responsible for the formulation of monetary, credit and foreign exchange policies. The Currency Committee comprised three cabinet ministers and one representative of the British and of the US delegation each. Because decisions were taken unanimously, foreign aid representatives had veto power. This increased the credibility of the program and finally succeeded in taming inflation. (Makinen, 1986)

Nonetheless, the tight control over credit policy exercised by the Currency Committee all but eradicated bank lending to industry. As a result, internal financing via retained earnings was

\footnotetext{
${ }^{13}$ The redistributive properties of such measure could not pass unnoticed. This forced transfer to borrowers which often enough were wealthier than average created a serious dent in the legitimacy of the emerging postwar regime.

${ }_{14}$ In 1947, the Governor of NBG reports to the Porter mission that NBG's share on capital in manufacturing firms rose from $6.4 \%$ in 1939 to $24.05 \%$ in 1945 . (Historical Archive of NBG, AII32Y1Ф33)
} 
the only alternative available to firms. ${ }^{15}$ Clearly, this policy favored incumbents, by creating barriers to entry, and hence maintaining industry structure concentrated.

Access to foreign-aid funds was essentially the only external source of financing for firms. Indeed, under various guises (the Marshall Plan being the most important of them) Greece received during the period 1944-1953 about 2.57 billion USD (Sweet-Escott, 1954). ${ }^{16}$ The US agencies were rather cautious to extend economic reconstruction funds to the industry as long-term subsidized loans. Loans to manufacturing firms amounted only to 50 million USD over the entire Marshall Plan period (Stathakis, 2004). Still, given the complete lack of alternative funding sources and the expectation that these loans would eventually never be repaid in full (as it actually happened in many cases), the program drew a lot of attention from most firms and became a coveted prize. As result a frenzy of influence activities took place. The main vehicle through which incumbents lobbied was the NBG, which was pressing the Greek government and the US delegation to relegate the management of the loan program to the commercial banks (in reality to NBG itself). Paul $A$. Porter, the head of the US delegation in 1946-48, was fending off such involvement; at the end though the Currency Committee partially gave in to the demands. ${ }^{17}$ Almost 43 out of these 50 million USD were given to just ten "large" manufacturing firms (operating in cement, steel, chemical and other heavy industries) creating thus a compact group of "national winners" (Stathakis, 2004).

During WWII the Greek shipping industry was all but destroyed. ${ }^{18}$ Within the auspices of the US aid, 100 "Liberty" ships were offered to the Greek government, which were distributed to the old ship-owners, who then managed to acquire 300 more ships reviving the Greek shipping industry. Since the shipping industry was the only internationalized sector, it was the only one that had access to foreign finance. As a result, the strong pre-war closely knit group of ship-owners regained its power and its ability to influence policy. ${ }^{19}$

\footnotetext{
${ }^{15}$ Indeed, in the late forties manufacturing firms were operating with extraordinary large profit margins, often as high as 300\% (UNRRA conjectures as reported in Stathakis, 2004). This feature of Greek capitalism has proved to be remarkably prescient.

${ }^{16}$ This represented about $20 \%$ of GDP during this period. Almost half of this aid was channeled towards military purposes, as during the first part of that period the Civil War in Greece was still rampant.

${ }^{17}$ This stand-off took place in late 1948. We believe it is interesting to mention that the Chairman of the Board of NBG, Alexandros Diomidis, stepped down in 1949 to become first Vice-President of the Government and then Prime Minister.

${ }^{18}$ Roughly $80 \%$ of its pre-war fleet was sunk, while in requisition service for the allied forces.

${ }^{19}$ The ship-owners' power is attested by the following excerpt from an interview given by Paul $R$. Porter in the 1990s (available at http://www.trumanlibrary.org/oralhist/porterpr.htm), who was Chief of the Economic Cooperation Administration Mission to Greece (1949-50). Porter states: “... one of our big problems was to get the ship-owners to pay taxes. They were about three years in arrears in taxes, and this represented a pretty large sum of money. Finally, we had to insist that the Government refuse shipping documents to any Greek ship-owner who was in arrears in taxes. Now, it took a lot of arm twisting to get the Government to agree to that. Always within the Government were people pressing us to twist their arms even more. It was actually a pretty courageous decision for the Greek Government to make considering how dependent so many of the Government officials were on the ship-owners, and also interlocked with them by marriage, family relationships. The amount of taxes that were collected was about 17 million dollars in one week." To appreciate how
} 
At the same time that the Greek government was reviving a ruined economy, it was also trying to avert a humanitarian crisis, imposed in part by a brutal civil war. Without the humanitarian aid of UNRRA and of the British and US agencies, this crisis would not have been averted. The inability of raising tax revenue and the expressed goal towards balancing the budget was precluding the government from instituting any sort of social spending programs. ${ }^{20}$ As a result the government brought back in full force the corporatist system that was instituted in the pre-war period by the Metaxas regime to protect social cohesion and to avoid leakages of the general population towards the communist insurgents' ranks. This created the basis for a coalition involving professionals, self-employed and shopkeepers, whose support for the "liberal" regime (as opposed with communism) hinged on their being granted with privileges at the expense of third parties (e.g., third-party taxes supporting pension funds or government-sponsored collusive price setting).

\section{Catching-Up: 1953- 1973}

The devaluation of 1953 is considered a milestone among the researchers of Greek economic history ${ }^{21}$, as it set the stage for a long period of rapid growth. Indeed, in 1973 GDP per capita in Greece was 3.32 times higher than its level in 1953, whereas the corresponding number for the average of 12 advanced Western European (12WE) countries was 2.14, for Portugal 3.07, and for Spain 3.03. ${ }^{22}$ To a large extent, this, widely-quoted, above-average performance of the Greek economy reflects normal catching-up episodes. It also reflects the medium-run successes that often accompany high rates of domestic saving and capital accumulation as the economy shifts from low-productivity sectors (i.e., agriculture) to highproductivity ones (i.e., manufacturing). During this period, the share of services in GDP remained constant (at 50\%), whereas the share of the secondary sector increased by 15 percentage points (from $20 \%$ in 1953 to $35 \%$ in 1973). ${ }^{23}$

Although the shift away from agriculture to manufacturing has been a feature of many latedeveloping economies, the constancy of the share of services requires some explanation. This was due to conscious policy exercised by the Currency Committee, which remained an important feature of economic policy until its demise in $1982 .{ }^{24}$ The Committee was the preeminent manifestation of state autonomy in the sense of rising above the demands of various socioeconomic groups and focusing on a developmental strategy which relied on

\footnotetext{
large a sum this was, we note that if it represented today the same share of GDP as it was then, it would be about 2 billion euros.

${ }^{20}$ In 1945, even foreign aid goods were being sold instead of being distributed freely, as this was the only mean available to the government to raise revenues. Actually, these sale receipts were expected to comprise $75 \%$ of government revenues, which was nonetheless not materialized (Makinen, 1986; Karatzas, 1988).

${ }^{21}$ The Greek drachma lost $50 \%$ of its value against the dollar.

${ }^{22}$ All figures pertaining to the evolution of GDP per capita are, unless otherwise stated, calculated from Maddison's (2010) data.

${ }^{23}$ This was the highest share that the secondary sector ever achieved in Greece. Our calculations are based on data drawn from Bank of Greece (1980), and the Ameco Database.

${ }^{24}$ Of course, after the conclusion of the Marshall Plan all foreign representatives had stepped down and the Bank of Greece was playing the prominent role as it was responsible for designing and proposing policy measures which were, usually, adopted by the Committee.
} 
extensive interventionism in the allocation of credit, the stated aim of which was to encourage manufacturing and exports, and to restrict consumer and trade finance.

In the 1950s industry structure remained rather concentrated..$^{25}$ This was a direct result of the fact that most firms were catering to the "small" domestic market. The few export oriented firms, were established in raw materials related sectors. On top of that, there were substantial barriers to entry. Import substitution policies protected local industry from foreign competition and as a result home-grown "national winners" were nurtured.

Limited financing opportunities played an equally important role in the propagation of oligopolistic structure in most industries, as they favored incumbents (i.e., "national winners"). Access to external financing was scarce. Equity financing was in its infancy (way below prewar levels) and bank financing was the only alternative mode of raising external capital. One has to stress though that banks were not only playing their traditional lending role but, more often than not, they were also acquiring direct ownership stakes in the incumbents. ${ }^{26}$ This created relational vested interests in the banks, which were thinking twice before financing new, possibly competitive, ventures. The extremely concentrated structure of the banking sector (that was essentially a duopoly) exacerbated these "perverse" incentives. ${ }^{27}$ Actually, it has been argued that incumbents have been "overleveraged" to such extent that banks have been subjected to severe moral hazard risks (Chalikias, 1976).

Essentially, internal financing via retained earnings was the only alternative for start ups to grow. Indeed there were several success stories that managed to grow via this channel in high profit margin sectors, but no doubt it tilted the balance in favor of the incumbents. As a result, almost all firms were essentially family-run. The only significant minority blockholdings were owned by banks, which were in a better position to influence management and exercise control than any other minority shareholder. As there was no real demand for the establishment of transparent corporate governance and investor protection rules, the lack of external financing was perpetuated, bootstrapping the evolution of industry structure in many sectors.

Meanwhile, protective regulations in many services allowed most self-employed professionals (lawyers, engineers, doctors etc.) to substantially benefit from the rapid growth path of the economy. The corporatist system of guild-like trade unions and professional associations was kept intact. Through an ever growing web of decrees, they were elevated to a semi-official regulator status, and they were given the authority, for

\footnotetext{
${ }^{25}$ Bourlakis (1996) reports that during the period in question the average "employment-share Herfindahl Index" in 85 three-digit manufacturing groups was increasing over time, signaling in increase in market concentration.

${ }^{26}$ As we have already stated, during WWII the NBG increased dramatically its share on capital in many "large firms".

${ }^{27}$ Until 1958 the banking sector in Greece can be described as a monopoly, with a competitive fringe. On that year, Stratis Andreadis (one of the key empire-builders of that era) managed to consolidate in one group three of the most important competitors to NBG and create a second large player in the market.
} 
example, to regulate entry (via permits or licenses), to set prices, to impose penalties on their members, and even to the general public through the imposition of taxation whose revenue were earmarked for the benefit (e.g. pension funds) of their members. As a result, they were able not only to cater to their interests but also to mitigate internal free-riding problems.

The last years of this period (i.e., post-1967) were marked by the colonel's junta. By reducing the importance of the Currency Committee, the dictators became unconstrained in the sense that large corporate-welfare handouts were given to many incumbent or regimeaffiliated entrepreneurs. The result of this lax credit policy, that was essentially based on arbitrary criteria, was to solidify the widespread feeling that Greek capitalism was of the crony-variety (as it later came to be called) which characterized most of the middle-income countries of that era. One may well describe this period as one of concentrated or oligopolized rent-seeking.

\section{Overt Populism: 1973-1993}

The next twenty years (1973-1993) started with the restoration of democracy in 1974 and the establishment of the Third Republic. This period includes the rise of PASOK (the Panhellenic Socialist Movement) to power and EEC entry (as the EU was then called) in 1981, and ends with Greece's decision to aim for accession to the EMU. The rather haphazard way in which the expansion of the public sector took place, along with the careless macroeconomic management which characterized (most) of this period, led to economic stagnation, rise in the unemployment rate, and culminated with a rise of the public debt to dangerously high levels. The performance of the Greek economy not only weakened considerably relative to the previous twenty years, but it was now worse than the average of 12 Western European (12WE) countries $^{28}$; in 1993 GDP per capita in Greece was only 1.30 times higher than its level in 1973, whereas the corresponding numbers for the average of 12WE countries was 1.40, 1.58 for Portugal, and 1.60 for Spain.

The dismantling of repressive political mechanisms after 1974 meant that governments had to rely on social and economic policy measures in order to garner political support. The growing societal demands, along with the willingness of the then conservative governments to appease an electorate that was all too eager to resume the radicalism of the 1960s, led to a transfer of power from the state to society, or rather, from a moderately-effective state bureaucracy (the semblance of a strong state in the Weberian tradition) to groups that claimed to better represent society's interests (Pagoulatos, 2003). The growing influence of trade unions and employer associations (especially of public-sector and state-ownedenterprises trade unions), in combination with the politicization and weakening of the autonomy of the bureaucratic apparatus after 1981 paved the way for the gradual transformation of the Greek state administration from an almost "developmental state" to

\footnotetext{
${ }^{28}$ These are: Austria, Belgium, Denmark, Finland, France, Germany, Italy, Netherlands, Norway, Sweden, Switzerland, and the UK.
} 
an "intermediate state". During this period the older individualistic (or family-based) system of patron-client relationships was supplemented by one dependent on favors bestowed on party members by the party machine (Charalambis, 1989).

The conservative (New Democracy) governments of 1974-81 increased spending on social insurance; whose share of GDP rose from $11.3 \%$ of GDP in 1974 to $16.4 \%$ in 1981 . However, these changes did not stem the tide of popular opinion; a broad segment of the public was demanding a change from the post-civil war socioeconomic regime which, they perceived, had effectively marginalized large segments of the population by conferring undue privileges to a handful of citizens ${ }^{29}$, and which the 1974-81 conservative governments did little to upset. Conspiracy theories about "the one-hundred families" that run the country acquired an almost religious credo among large segments of the population. ${ }^{30}$

The success of this classification (orchestrated by PASOK) was that few could openly identify themselves with the "privileged", and hence policies aiming to relinquish their economic or political power got wide acceptance. It is thus no wonder that PASOK's declared aspirations of popular sovereignty and social liberation appealed to an electorate eager to experience social participation so as to ensure that "...the basic economic choices are made by the social whole." It was also believed that by transforming the institutional framework these "structural reforms" would provide the basis for the modernization and development of the Greek economy (Tsakalotos, 1998).

Putting thus an end to "a long-lasting post-civil-war regime" (Spourdalakis, 2008), PASOK managed to express, represent and legitimize a heterogeneous range of collective demands that were excluded from the political arena. However, these demands often failed to satisfy broadly desired social objectives. A particularly poignant example concerns PASOK's intention to create "decentralized organs of social control", which was essentially a euphemism for its attempt to transfer control over semi-public and even private sector firms to union members affiliated with the party. This was accomplished via the "socialization" of public enterprises according to which formal authority passed to supervisory councils consisting of representatives of management, workers, local authorities, and the state. In addition, several large private sector firms got nationalized via the creation of a new state holding company, whose objective, supposedly, was to restructure these so-called "ailing" firms, some of which were heavily leveraged, and deemed insolvent. All these efforts failed to achieve their stated objectives of "social control", but were immensely successful in assigning to party affiliated union members the real power of redistributing resources. As a result, they were used for furthering PASOK's electoral aspirations, and for "democratizing" rent-seeking opportunities.

\footnotetext{
${ }^{29}$ These were named in the public discourse as the "privileged".

${ }^{30}$ We are not interested in ascertaining if the public's perception was justified, in any sense. Instead, we take a positivist approach on this matter and try to explain how this "ideological bias" influenced public's attitudes towards specific policies. Di Tella and MacCulloch (2009) provide international evidence in support of the notion that citizens' perceptions about corruption reduce their willingness to support "free-markets" policies and induce them to demand more regulation.
} 
The democratization or proliferation of rent-seeking was the main by-product of the infiltration of every aspect of economic and social life. This was achieved by replacing the old patron-client relationships in which relatively few policymakers and administrators were able to dispense favours to a select few, to a system in which the power was dispersed by allowing a large number of lower-ranked, but party-affiliated, bureaucrats and trade unionists to, effectively, exercise veto power in practically all decisions which required the involvement of any state or quasi-state agency. ${ }^{31}$ Such "bureaucratization of clientelism" (Lyrintzis, 1984) and open disregard for the integrity of institutions was aided by public pronouncements of government ministers (including Premier Andreas Papandreou ${ }^{32}$ ), which encouraged PASOK apparatchiks to colonize the bureaucracy and to control most of the associational activity (e.g. trade unions, professional associations, farmer's cooperatives, academic departments, even employer's associations). ${ }^{33}$ It was also aided by the proliferation of laws and regulations, supposedly intended to close the loopholes for unlawful conduct, but which, in effect, were functional in entrenching both clientelistic politics and rent-seeking opportunities.

These developments, along with the decreasing profitability and influence of industrial capital, incentivized existing or aspiring entrepreneurs to form alliances with party functionaries, and to concentrate their activities in sectors in which subsidies and public procurement were relatively plentiful. Worse still, the rent-seeking aspects of clientelistic politics were further enhanced by the gradual weakening of the "authoritarian" civil-service code, which opened the way for widespread anomie among civil servants, who quickly realized that affiliation with the party in power increased both their chances of promotion and, effectively, guaranteed non-punishment for unlawful conduct. The attraction of PASOK to existing and aspiring public-sector employees can be gleaned from the following data: as the number of public-sector employees nearly doubled in the 1980 s (from about ${ }^{34} 500,000$ in 1980 to over 900,000 in 1989), the vast majority of new appointments were PASOK supporters; according to a 1986 study (cited by Pridham and Verney, 1991), PASOK more than tripled its membership between 1981 and 1986, and 89\% of PASOK members who joined the party since 1981 were employed in the public sector.

\footnotetext{
${ }^{31}$ A useful ideological construction which PASOK exploited with repeated success was that its predominant aim was to empower precisely the political and social groups whose legitimate representation had been thwarted in the past. For this reason it "invented" a new historical-political subject, the "non-privileged", thus appearing as the sole carrier of the "people's voice", of the people's resentments and frustrated expectations.

${ }^{32}$ Pesmatzoglou (1993) credits Andreas Papandreou with the phrase "There are no institutions, there is only the people."

${ }^{33}$ Board elections in these associations were transformed into party contests, closely monitored by the press. For example, even the annual university and high-school student elections became major political events.

${ }^{34}$ The use of the word "about" is intentional. The government never had (or, revealed) any precise knowledge of the number of general-government employees - mainly a result of the unwillingness of various Ministries to reveal the number of civil servants employed in their core operations and in the public enterprises under their control. In 2010, under the lender's (EU/ECB/IMF) pressure the Ministry of Interior announced a precise number, which, however, did not go undisputed.
} 
PASOK's policy is more aptly understood as populist, since it was not mainly focused on class cleavages given the absence of a significant cleavage in Greek politics along class lines. This has been due to the relatively small industrial base and small number of industrial workers. Already in the 1980s, public-sector employees and the self-employed (about half of which were in agriculture) were making a social majority (Tsoucalas, 1987)..$^{35}$ Moreover, studies of voting behavior in Greece (Gunther and Moreno, 2001) suggest that indicators of economic/social class are much weaker as predictors of the vote in Greece along the Left/Right axis than they are in other West European countries. ${ }^{36}$ This is not surprising since, in Greece, class structure is less polarized and wealth inequality is small compared to other European countries (Katsimi et al., 2013). ${ }^{37}$ This may appear as running counter to the previously described prevalent perception of social injustice; but this may be just one of the instances where the beliefs-driven public discourse is devoid of facts.

These features of Greek society meant that PASOK - in the 1980s - could count on broad political support provided that it availed to large segments of Greek society specific "public goods". Among these "public goods", the most important - in their ability to procure mass political support - were: employment in the wider public sector at relatively high wages; a lax enforcement of tax law for the self-employed; and the granting of (mostly) unfunded pension rights to various groups - these included the provision of public pensions to persons without prior contributions, and the provision of excessively large pension benefits to selected groups of public-sector employees (including, especially, to those employed in state-owned enterprises and banks) and to the self-employed. ${ }^{38}$ In addition, the presence of EU funds allowed the governments since the mid-1980s to secure media support through selective channeling of funds to friendly media moguls - who often enough happened also to be winners of lucrative public procurement contracts.

Ironically, the dismal economic performance of the PASOK governments in the 1980s did not produce a large dent into its popularity among the voters. In fact, the rise in the unemployment rate from less than 3\% in 1981 to $8 \%$ in 1988 increased PASOK's ability to act as a patron to broad segments of the population, since it became particularly adept in the skillful manipulation of scarcity. PASOK's cadres came to realize that patron-client

\footnotetext{
${ }^{35}$ Egalitarian patterns of land ownership resulted from redistribution of agricultural lands seized from the Ottoman Empire in the course of a series of territorial annexations up until World War I. In addition, aggressive land-reform policies under the governments of Eleftherios Venizelos especially following the massive influx of Greek refugees from the disastrous Asia Minor campaign of 1919-22, led to nearly universal land-ownership among the rural population of Greece. Mavrogordatos (1983) reports that in 1928, $64 \%$ of the labor force either owned their own businesses or agricultural lands, or were working for other family members, while just over $9 \%$ of the labor force were employed as manual workers in the industrial sector.

${ }^{36}$ It bears noting that even for the Orthodox Communist Party (KKE) no more than 7 percent of its votes can be explained by objective indicators of social class.

37 This implies that political polarization in Greece along a left-right cleavage was anchored in historically constructed political identities, and in the individual welfare consequences of a giant spoils system (Mavrogordatos, 1983).

${ }^{38}$ See Matsaganis (2011) for more details regarding the inequities and inefficiencies of Greek social policy.
} 
relationships need not depend on a continuous stream of publicly provided benefits but on sustaining the expectation of rewards in the maximum number of would-be voters for the party with the minimum payoff in concrete benefits. Some of these could be the (relatively) lucrative employment opportunities created by the overstaffing of state-owned enterprises. Naturally, these opportunities were to some extent limited by the lack of government revenue and the inability to borrow from abroad. Yet, there were other means through which patron-client relationships on a large scale could be fostered. Often enough these involved preferential access to scarce public goods and services, which, although in principle were accessible to all citizens, their (timely) availability depended on being able to draw on the goodwill of the party's cadres, or on family relatives who happened to have been publicsector employees at crucial posts.

Borrowing from Olson's metaphor (Olson, 2000) - and in distinction with the "stationary bandit(s)" regime of the first three postwar decades which had a stake in growth as long as it afforded its members a portion of the increased output without jeopardizing the survival of the regime, the post-1981 regime could be interpreted as a "roving bandit(s)" regime, in which, literally, tens of thousands of civil servants and private agents could overtly engage in rent-seeking activities (and covertly in unlikely-to-be-punished outright corruption) without, rationally for each player, too much regard for the detrimental growth effects of such behavior. In essence, a "growth-without-too-much-trickle-down" regime was replaced by a growth-retarding, "plough-into-the-public-coffers" regime. ${ }^{39}$

\section{Stealth Populism: 1993-2008}

The final fifteen years (1993-2008) before the start of Greece's sovereign debt crisis, saw a further expansion (along with some rationalization) of the welfare state, fast growth rates, and EMU entry. The Greek economy appeared to perform better as in 2008 Greek GDP per capita was 1.65 times larger than its 1993 level, whereas the corresponding numbers for the 12WE was 1.31, 1.29 for Portugal, and 1.61 for Spain. ${ }^{40}$

The parliamentary elections of 1993 returned Andrea Papandreou's PASOK to power after a brief interlude (1990-93) in government of the conservative New Democracy under its more liberal-minded leader Constantine Mitsotakis. New Democracy's return to power followed on a series of high-profile corruption cases brought against senior PASOK officials, ${ }^{41}$ and in the wake of three consecutive elections, Mitsotakis eventually received enough support to form a government with a very weak parliamentary majority. This compromised

\footnotetext{
39 The "democratization" of rent-seeking became so entrenched that even the Conservative Party (New Democracy) adopted it wholeheartedly while in power (2004-9).

${ }^{40}$ With the benefit of hindsight we know that the "growth model" of this period was seriously flawed, as it was predicated on excessive borrowing from abroad; the global financial crisis put the tombstone to this phase, and ushered-in the Greek Great Depression, taking the unemployment rate to 27.2\% (as of January 2013), and returned Greek GDP per capita as percentage of the corresponding measure for the $12 W E$, to the level it was in 1972.

${ }^{41}$ Even Andreas Papandreou was brought to trial during New Democracy's reign, but he was acquitted in January 1992 after a ten-month trial by a 7-to-6 margin.
} 
seriously the government's ability to carry out its avowed aim of economic liberalization, and it was eventually forced to call early elections, which it lost, in 1993.

PASOK's return to power can only partly be explained by the lackluster economic performance of Mitsotakis's government - after all, PASOK's past performance was equally unimpressive. It can mostly be explained by the widespread perception that, despite its manifest shortcomings, PASOK represented the only alternative if the country was to consolidate the wealth and power redistribution achievements of the last two decades, and to put a brake on the return of the "unfair capitalism" of the postwar decades. The large decline in income and consumption inequality, which had taken place in Greece since 1974, and especially the rise in the income and consumption shares of the middle of the distribution relative to the top (Mitrakos and Tsakloglou, 2012) meant that the mediocre growth record of the 1980s was not incompatible with increases in the living standards of the "median voter".

Moreover, PASOK was gradually shedding some aspects of its "third-world populism". Given the publicly stated objective to aim for participation in the EMU, and under pressure from its "modernizing wing" - which eventually ruled the country from 1996 to 2004, PASOK altered its agenda and adopted privatization and liberalization policies. ${ }^{42}$ At the same time, it managed $^{43}$ to tame budget deficits and inflation, and Greece acceded to the Eurozone on January 1, 2001.

One may have thought that the reduction of budget deficits during this period would have been accomplished by tightening wasteful public spending, thus reducing opportunities for rent seeking and outright corruption. However, from 1993 to 2000, the share of tax revenue in GDP increased by about 8 percentage points whereas the share of government spending remained intact. More importantly, primary government spending (i.e., excluding debt interest payments) was rising during the pre-EMU period, since interest payments were steadily declining as a result of nominal convergence (i.e., drop in nominal interest rates) to the rest of the euro-area countries. The boost given to the Greek economy by the reduction in real interest rates and the foreign capital inflow allowed for a huge rise in the real value of primary government spending, which increased by $110 \%$ between 1993 and 2008 .

Given the diachronic inability of the Greek state to collect taxes, the rise in tax revenue mentioned above would be no mean achievement if one is interested in meeting a revenue target. Yet, this rise in tax revenue - which managed to arrest the large rise in public debt since 1981 - was partly achieved by allowing an unsustainable string of current account deficits. $^{44}$

\footnotetext{
${ }^{42}$ Ironically, this meant that it ended up adopting some of the policies it fought hard to stop New Democracy from implementing.

${ }^{43}$ We explain below how this was achieved.

${ }^{44}$ Assuming away the Ricardian equivalence hypothesis, it is usually thought that a higher budget deficit leads to a higher current account deficit - the "twin deficits hypothesis". (This is not necessarily the case though, since it is the sum of private, government, and foreign sector balances that must be
} 
For reasons related to the financial liberalization laws enacted in Greece in $1994,{ }^{45}$ international borrowing (mediated through the domestic banking sector) became easier and households started being able to borrow far more in order to finance purchases of consumer durables (and at lower real interest rates as well). This unprecedented (for Greece) credit expansion, led to a huge deterioration in the current account balance; from a surplus of $1.3 \%$ of GDP in 1994, to a deficit of $12.0 \%$ in $2000 .{ }^{46}$ At the same time, (nominal) government revenue tripled during the same period. ${ }^{47}$ This was a result of the huge rise in imports; from $24.9 \%$ of GDP in 1994 , to $38.4 \%$ in 2000 . The reason is that imports which suddenly become possible through (international) borrowing need not (necessarily) displace spending on domestically produced goods (they may even increase it!), and create a revenue boon for the government. ${ }^{48}$

The tight time constraints that had to be met if Greece was to be a member of the euro area from the first day of the physical introduction of the euro (January 1, 2002), meant that the Greek governments faced a very difficult task if they were to meet the 3 percent budget deficit limit required for gaining accession to the euro area. Leaving aside the charges that Greece "cheated" in its presentation of budget data, one may well understand why the Greek governments were willing to allow, temporarily, for a large increase in net foreign indebtedness if that helped in achieving the "national goal" of euro area participation. Unfortunately, even after the EMU-accession decision, it proved impossible for the Greek governments to arrest the continuing rise of net foreign indebtedness, since large capital inflows (i.e., large current account deficits) continued to be an easy way for keeping budget deficits not "too far" above the 3 percent limit. ${ }^{49}$ Thus, a more malign (since it was increasingly mortgaging the country to the rest of the world) and covert populism substituted for the overt populism of the previous period.

That the exigencies of political necessity would make it difficult to reverse the dangerous path of excessive-credit-creation-based budget "consolidation" became apparent during the pre-election campaign of 2000. In a tightly fought electoral battle, the party in power (PASOK) promised that citizens would receive their due - and delayed - reward of increased "welfare provisions", since the goal of EMU entry had been achieved. ${ }^{50}$ Following their

equal to zero.) Implicit in this presumption however, there is, inter alia, another presumption: that causality runs from budget deficits to current account deficits. Nevertheless, the direction of causality can also run from the current account deficit to the budget deficit as we argue in the text.

${ }^{45}$ Financial liberalization was a pre-condition for being admitted to the euro area.

${ }^{46}$ The current account deficit widened further to $16.3 \%$ of GDP in 2008.

${ }^{47}$ The ratio of government revenue to GDP increased from $34.8 \%$ in 1994 , to $40.1 \%$ in 2000 .

${ }^{48}$ For example, car imports generate immediate tax revenue (VAT, luxury taxes, etc). They also allow for increases in domestic value added (e.g., services related to sales, advertising, and repairs of automobiles), thus allowing for second-round increases in income tax revenue. In general, the smaller is the substitutability between domestically produced and imported goods, the larger will be the rise in domestic output due to higher imports which are financed by capital inflows.

${ }^{49}$ In fact, Greece violated for every year between 2000 and 2008 the $3 \%$ limit on budget deficits, frequently being above $5 \%$. See, Katsimi and Moutos (2010) for a discussion of this and the difference between the "first release" of the budget deficit, and the latter estimates of it.

${ }^{50}$ Although the elections were held in April, and the formal decision was taken in June 2000, it was known many months before that the Council would approve Greece's EMU participation. 
electoral win (by a very small margin), the government proceeded in "rewarding" citizens (i.e., their electoral base) with large increases in public-sector wages ${ }^{51}$ (Moutos and Tsitsikas, 2010) and pensions (Tinios, 2012). In effect, in the pre-EMU accession phase, the threat of exclusion acted as a hard budget constraint that forced the Greek government to redress its fiscal imbalances (in the way described). In contrast to the output-driven, "hardconditionality" of the pre-accession period, the EMU period was characterized by the "softconditionality" of the Stability and Growth Pact, which allowed Greece (even more than other governments) to breach both the letter and the spirit of the Pact.

By this time, successive Greek governments depended not only on their traditional electoral bases, but on the banking sector. The gradual liberalization of the banking sector, which started in the late 1980s and got a large boost due to the financial liberalization laws of 1994, allowed - until the crisis erupted - for a happy symbiosis between the banking sector and Greek governments. Both government and banks were locked in a growth-on-(foreign) credit -steroids regime which, as long as foreign credit to both parties was available, allowed Greek governments to continue their clientelistic politics, and the private sector (mainly the banks) to postpone the consequences of their increasing foreign indebtedness. The banking sector re-entered to the nexus of key players who were fatally tied to a regime of (literally) borrowed growth - as any substantial lowering of foreign credit expansion would harm both the government and banking sectors whose revenue and viability dependent on an unsustainably large GDP growth rate (due to the huge current account deficits it was producing). The regime could go on only as long as soft budget constraints were allowed to rule.

Nothing exemplifies this era's attitude of soft budget constraints than the way social transfers were wasted. Although in the 2000s Greece managed to catch up with the rest of EU Member-States as far as social spending is concerned, it has been unable to tilt its social policy towards the categories of the population which receive minimum or no social protection. The waste involved with respect to social transfers in Greece can be gleaned from their (in)effectiveness in reducing poverty-risk. EU-SILC data (ELSTAT, 2012) indicate that from 2003 to 2008 the average reduction in the at-risk-of-poverty-rate was 3\% in Greece, whereas among the EU15 countries the average reduction in the at-risk-of-povertyrate for the total population was $10 \%$. (The poverty rate in Greece before social transfers was about the same as in the EU15.) These data not only underscore the inability of the Greek state to use social policy effectively, but they also reflect the willingness of Greek policymakers to cater to special interest groups.

A prime example of this inefficiency is the social security system; a highly fragmented payas-you-go system that comprised the vast majority of government social expenditure. Between 1980 and 2007, government expenditure on old-age pensions as share of GDP more than doubled; from $4.6 \%$ to $10.0 \%$ of GDP. A few examples, which show how pension

\footnotetext{
51 The cumulative increase over the 1995-2009 period in (gross) nominal private sector wages (excluding the banking sector) was $116 \%$, whereas the cumulative increase in civil servant's wages was $159 \%$, and in publicly owned enterprises 221\% (Fotoniata and Moutos, 2010; EEAG, 2011).
} 
funds serving "special-interest" groups managed to attain their privileged position - usually achieved by receiving indirect subsidies by the government (often by imposing taxes on third parties) - should suffice. Matsaganis (2011) reports that the same amount of contributions would give a pensioner of IKA, which is the main social insurance fund catering to privatesector employees, a pension of $€ 500$ at age 65 , while it would give a pensioner of TAP-OTE (a fund catering to a telecom firm which was, until recently, publicly owned), $€ 1,500$ at age 55 . Such unequal treatment of pensioners, which was underpinned through the use of public funds, was also responsible for the higher incidence of poverty among pensioners than for the population as a whole. It is thus ironic that social transfers (excluding pensions) in Greece were very effective in reducing the high (relative to EU15) at-risk-of-poverty-rate for persons older than 65 , while at the same time government policy was responsible for creating the high poverty risk among pensioners by over-subsidizing through scarce public funds the more "affluent" pension funds. ${ }^{52}$

The soft budget constraints, due to low cost access to finance from the international markets, were only one part of the story. The EMU liberalization and privatization agenda was incompatible with the continuation of catering to party cadres needs via the expansion of an already bloated public sector. The result was to outsource the redistribution-ofresources facility. State-owned enterprises could not be relied upon to be the sole "intermediaries" available for achieving this objective any longer, as they were coming under scrutiny. The rents redistribution facilitator role was taken by many private entrepreneurs, who were interrelated with the party machine. These private actors become the beneficiaries of lucrative public procurement contracts, and led to widespread graft as it created an "industry" whose role was to facilitate "information exchange" and "matching" between government functionaries and private actors. A side-effect of taking the redistribution of resources "private" was probably an increase in the inefficiency of the process, due to the extra effort needed to hide (or legalize) these arrangements. It is probably no coincidence that during this era Greece's ranking in Transparency International's index of corruption declined from $36^{\text {th }}$ in 1998 , to $44^{\text {th }}$ in 2002 , to $49^{\text {th }}$ in 2004 , to $57^{\text {th }}$ in $2008 .^{53}$

We end this section by noting an instance in which well-intentioned attempts to rationalize public sector hiring that were undertaken at the start of this period had unintended consequences. To establish an element of efficiency and/or justice in the hiring decisions, an independent administrative body overseeing public sector hiring (named ASEP) was instituted. Given the cynical social environment within which it was functioning and to avoid accusations of preferential treatment of party affiliates, ASEP tried to establish "objective" criteria, which were supposed to promote meritocracy. Among these criteria, education was

\footnotetext{
52 The inequities of social protection in Greece are not restricted to just old-age pensions; they permeate all aspects of it. For example, blind people receive €362 (per month) if they are students or employees, and €697 if they are lawyers; the low-income family benefit is €25 (per month) if the parents are private-sector employees, and $€ 236$ if they work in the wider public sector or in a bank (Matsaganis, 2011).

${ }^{53}$ The inclusion of more countries in the index is only marginally responsible for this deterioration in ranking.
} 
playing the predominant role. Suddenly, a tertiary education degree (no matter what the subject or the quality of the institution) became a valued passport to land a lucrative public sector job. ${ }^{54}$ As a result, getting into a university (or even into a technical higher education institute) became a coveted prize - regardless of the actual intrinsic value of the degree. Competitive university entrance exams increased in importance and acquired an almost lifedefining role. Not surprisingly, families started preparing their off-springs for these exams early on (already from junior-high school) by hiring tutors or by attending private crammer schools - most of which operate in the black economy. This meant that secondary education was subordinated to the university entrance exams, leading to a considerable reduction in the quality of education high schools were offering and moreover to a hemorrhage of family budgets, which were essentially willing to dissipate the expected university-degree rents. ${ }^{55}$

The political hold on the provision of tertiary education in Greece is so unique that it merits some discussion. The Greek Constitution does not allow private (even not-for-profit) Universities to operate in Greece. ${ }^{56,57}$ Thus, private spending on tertiary education in Greece as a percentage of total spending on tertiary education was only $0.3 \%$ in 2009 (OECD, 2012) - the lowest, by far, among all OECD countries, whose corresponding average was $22.9 \%$. Despite the small (official) presence of the private sector in education in Greece, public spending on education in Greece has been only 2.3\% of GDP for the period 1970-2005, whereas the corresponding number for the OECD average was $5.1 \%{ }^{58}$

It is not easy to interpret why Greece appears to underspend on education. For one thing, the numbers mentioned above do not include the considerable spending undertaken by Greeks studying abroad, and the (mostly) unrecorded spending on crammer schools

\footnotetext{
${ }^{54}$ For example, $69.5 \%$ of the new public-sector jobs allocated through the ASEP in 2004 were earmarked solely for tertiary education graduates. To appreciate the implied increase in the probability in getting a public sector job as a tertiary education graduate, it suffices to say that tertiary graduation rates have never exceeded $35 \%$ of the relevant age groups.

${ }^{55}$ Kanellopoulos et al. (2003) estimate that the share of education expenditures in household budgets (mainly on crammer schools and private tutors) rose from $2.15 \%$ in 1974 to $4.41 \%$ in 1999 . Recent studies (KANEP, 2009) estimate that in 2005 this figure had risen to $5.09 \%$ of household budgets. As a proportion of household spending for families with children in secondary school this can reach to more than $20 \%$ of household income (Psacharopoulos and Papakonstantinou, 2005).

${ }^{56}$ If, for example, a top US Ivy League University wanted to set-up a campus in Greece, the Greek state would not recognize the degrees conferred by it as equivalent to those provided by Greek universities; thus the graduates of any bona fide foreign institution operating in Greece would not be allowed to compete for the coveted public sector jobs, thus diminishing the attractiveness of a degree from such an institution. Even, when a degree is gained abroad, such degree can be recognized as equivalent to a Greek university degree, only after the graduate applies for the granting of "equivalence" to the designated Greek government organization (DIKATSA).

${ }^{57}$ In 2007, the latest effort to create a constitutional majority so as to amend the constitution in this respect was thwarted by George Papandreou's last minute decision to pull PASOK away from such a deal with the then governing New Democracy.

${ }^{58}$ Even in South Korea, i.e., a country with similar GDP per capita levels during this period, the corresponding number is $3.6 \%$. Furthermore, the above difference can be properly appreciated if one takes into account that in 2000 South Korea had a very large presence of private spending on (all levels of) education, i.e., $40.8 \%$ of the total, while in Greece it was only $6.2 \%$.
} 
mentioned earlier. ${ }^{59}$ Furthermore, one can argue that spending on education may be explained by Greece's specialization in low-to-middle-tech services (e.g., tourism and sea transport) which did not require a particularly sophisticated labour force for its operation thus making the vested interests of these sectors not particularly interested in seeing an improvement in public education. ${ }^{60}$ Nonetheless, this argument ignores that the industrial elite intervened and influenced the quality of tertiary and technical education degrees in the 1950s and 1960s when its demand for well-educated employees, especially engineers, boosted the post-war expansion of universities and technical schools. The interest of the industrial elite, though, receded in the post-1973 period. This 'neglect' can be attributed both to the withering importance industrial capital had in the economy from that period onwards, and to the increasing dominance that political parties and other "social groups" came to exercise over the public university system after the fall of the colonels' junta and the rise of PASOK to power. An important aspect of this over-politicization of tertiary education was the constant scrabble for ideological supremacy (often, but inaccurately, portrayed as a battle between those whose avowed aim was the provision of "societybenefiting" education and those who wanted a strong linkage between education and the private sector's labor market needs) and control over resources. ${ }^{61}$

Ironically, the avowed aim of insulating educational ideals from labor market needs was effectively reversed with the creation of ASEP. As explained earlier, in the post-1994 ASEP period, the public's main interest was to satisfy the increased demand for any tertiary education degree. (Apparently, "preparing" students for public-sector employment was not considered as a sacrifice to the ideal of "society-benefiting" education.) Fittingly, public spending on tertiary education increased from $0.6 \%$ of GDP in 1995 to become equal to the OECD average of $1.5 \%$ in 2005 . This represents, we believe, another instance of the democratization of rent seeking.

\section{Post-mortem: Greece's Great Depression}

The global financial crisis of 2007/08 took the Greek growth-on-(foreign) credit-steroids regime apart with a small delay. Once foreign credit to the overextended Greek banking sector collapsed, it took about a year before the "benefits" of huge current account deficits for the government budget deficit to evaporate. Indeed, for the first time after many years, in 2009 the government budget deficit was larger than the current account deficit. I.e., the

\footnotetext{
${ }^{59}$ But still, even if these types of private spending are properly accounted for, they would probably raise the "true" share of private spending on education in Greece from the recorded $6.2 \%$ of total spending close to the (recorded) OECD average of $12.2 \%$, but would certainly keep it far below the recorded $40.8 \%$ for Korea.

60 Acemoglu and Robinson (2012) provide many historical examples in which the "elites" showed either "benign neglect" with respect to the provision of public goods or were openly hostile to their provision - often caring not only about the extra tax burden, but also fearing that their provision would diminish their power to influence other types of policies.

${ }^{61}$ The Ministry of Education exercised an inordinate amount of control over the allocation of resources, often using public money in order to advance party-political interests and with blatant disregard to the detrimental consequences of these actions.
} 
collapse of foreign lending to the Greek private sector forced, through the channel explained earlier, a large rise in the government budget deficit.

Although it is common to attribute Greece's Great Depression ${ }^{62}$ solely on governments' profligacy, in fact, the private sector reduced its saving rate at the same time as the government was trying to decrease its own dis-saving from the early 1990s to the mid2000s. Indeed, it was the decline in the private sector's gross saving rate (from 27\% in 1988 to $11 \%$ in 2008), that led to large current account deficits after 1997, which took Greece's net foreign assets' position from $-3 \%$ in 1997 to $-86 \%$ of GDP by the end of 2009 (Moutos and Tsitsikas, 2010). At that point investors started to question the government's ability (and/or willingness) to service its debt to foreigners, since it became clear that the Greek government faced a mission-impossible; on the one hand, to make public debt sustainable, the economy should grow so as to increase tax revenue; on the other hand, to make net foreign debt sustainable, the economy should contract so as to eliminate the huge current account deficit. Under these conditions, foreign creditors started demanding interest rates that embodied a high probability of default, thus forcing the government to resort to the official bailout mechanism to avoid the impending (disorderly) default.

This brought an end to the large expansion of Greek living standards, but it remains to be seen whether the tutelage exercised, once again, by foreign representatives (from the $\mathrm{EU} / \mathrm{ECB} / \mathrm{IMF}$ this time) will manage to break the mould that gave rise to the changing political economy coalitions which appear to have been controlling events in Greece during the last decades. Some evidence of the acceptance (albeit grudgingly) of the policies implied by the bailout package can be elicited by the Eurobarometer (2010). ${ }^{63}$ There one could sense a change in attitudes by the Greek citizens, who have been raised to consider the government as "employer of last resort." Given that public sector employment was the main tool through which political parties in Greece dispense favours to partisan voters, as well a "redistributive" tool in periods of high unemployment, this change in attitudes is an indication that the foreign lenders (through their tutelage of the post-2009 Greek governments) have succeeded in refashioning the public debate about the role of the public sector in the economy.

A reason for the absence of a very hostile and open reaction (despite some flurries in June 2011) to the reform package by society at large is, first, the gradual recognition that

\footnotetext{
${ }^{62}$ The percentage drop in Greek GDP since 2008 is (circa Spring 2013) two-and-a-half times as large as the one experienced from peak to trough in the 1930s.

${ }^{63}$ The Eurobarometer (2010) reports results of interviews conducted between May 7 and May 25 in Greece, when most of the details of the bailout package had already been reported in the press. (For more details along these lines, see EEAG (2011).) In response to the statement "In a international financial and economic crisis, is it necessary to increase public deficits to create jobs" more people in Greece than any other European country have stated that they disagree (for Greece, 37 percent "Agree" and 53 percent "Disagree"; for the EU27, 46 percent "Agree" and 36 percent "Disagree"). If one takes these responses at face value, then a sea change in attitudes appears to have taken place in Greece during 2010. Unfortunately, previous issues of the Eurobarometer have not dealt with the same issue, and thus we do not have "direct" evidence of the change in attitudes.
} 
Greece's current predicament is a result of the deep entanglement between political and economic power that continues to engulf Greece, and, second, that absent the willingness of foreign lenders to accept further increases in debt accumulation it is only fair that the "entitled" levels of income and social welfare are lowered. ${ }^{64}$ There is also some recognition that Greece's current predicament has arisen because for a long time powerful key players have managed to legitimize and strengthen their position via the democratization of rentseeking, by permitting weaker players to also benefit by a system of inefficient policies (or, outright anomie) in which the pilfering of public resources remains largely unpunished. As a result, Greece has reached a frightening homeostasis which can be broken only if all the beneficiaries of the current politico-economic equilibrium lose their undue privileges. It remains unclear whether a significant number of voters - let alone the political parties have realized that this is the only way out of the current crisis.

\section{References}

Acemoglu, D. and J.A. Robinson, 2012, Why Nations Fail: The Origins of Power, Prosperity, and Poverty, Crown Publishers, New York.

Angelopoulos, K., A. Philippopoulos and V. Vassilatos, (2009) "The social cost of rent seeking in Europe", European Journal of Political Economy 25: 280-299.

Bank of Greece (1980) The Greek Economy: Research Essays and Statistical Series, Athens Bank of Greece (in Greek).

Bourlakis, C., (1996) "Concentration Trends in Greek Manufacturing Industries 1958-1984: An Entropy Approach", University of Leicester Discussion Papers No.96/6.

Chalikias, D., (1976) Potential and Drawbacks of Credit Policy, Athens: Bank of Greece (in Greek).

Charalambis, D., (1989) Clientilistic Linkages and Populism, Athens: Exantas (in Greek).

Clogg, R., (1987) Parties and Elections in Greece: the Search for Legitimacy, Durham, NC: Duke University Press.

Coase, R.H., (1937) “The Nature of the Firm”, Economica, 4: 386-405.

Dertilis, G. (1985), Social Transformation and Military Intervention, Athens: Exantas (in Greek).

Di Tella, R. and R. MacCulloch, (2009) "Why Doesn't Capitalism Flow to Poor Countries?", Brookings Papers on Economic Activity, 40: 285-322.

\footnotetext{
${ }^{64}$ Passarelli and Tabellini (2013) explain how the perception of fairness is endogenous, and how as external circumstances deteriorate individuals become resigned to a lower level of welfare. They also show that in such circumstances governments may engage in policy procrastination.
} 
EEAG (2011), The EEAG Report on the European Economy, "Greece", CESifo, Munich 2011, pp. 97-125.

ELSTAT (2012), Living Conditions in Greece, available at www.statistics.gr.

Eurobarometer (2010), Public Opinion in the European Union, Eurobarometer 73, European Commission, Brussels.

Fotoniata, E. and T. Moutos, (2010) "Greece: Neglect and resurgence of minimum wage policy", in Vaughan-Whitehead, D. (ed), The Minimum Wage Revisited in the Enlarged EU, Edward Elgar, Cheltenham U.K. and International Labour Office: Geneva, pp. 213-243.

Gunther, R. and J.R.Moreno, (2000) The Anchors of Partisanship: A Comparative Analysis of Voting Behavior in Four Southern European Democracies, Estudio/Working Paper 2000/150, Juan March Institute, Madrid.

Karatzas, G., (1988) "The Greek Hyperinflation and Stabilization of 1943-1946: A Comment on Makinen", Journal of Economic History 48: 138-139.

Kanellopoulos, C. N., Mitrakos, T., and Mavromaras, K. G. (2003) Education and Labour Market, Center of Planning and Economic Research, Athens (in Greek).

KANEP-GSEE (2009) Main Figures of Greek Education, Center for the Development of Education Policy, General Confederation of Greek Workers, available at www.kanep-gsee.gr.

Katsimi, M. and T. Moutos (2010), "EMU and the Greek Crisis: The Political Economy Perspective", European Journal of Political Economy, 26: 568-576.

Katsimi, M., T. Moutos, G. Pagoulatos, and D. Sotiropoulos (2013) "The (eventual) social hardship of soft budget constraints" in B. Nolan, W. Salverda, D. Checchi, I. Marx, A. McKnight, I. György Tóth, and H. van de Werfhorst (eds) Changing Inequalities and Societal Impacts in Rich Countries: Thirty Countries' Experiences, Oxford: Oxford University Press.

Kofas, J., (1989) Intervention and Underdevelopment: Greece during the Cold War, University Park: Penn State University Press.

Liakos, A., (1993) Labour and Politics in Interwar Greece, Athens: Foundation for Research and Education, Commercial Bank of Greece (in Greek).

Lyrintzis, C., (2005) "The Changing Party System: Stable Democracy, Contested Modernisation", West European Politics, 28: 242-259.

Maddison, A., (2010) Historical Statistics of the World Economy: 1-2008 AD, Groningen Growth and Development Centre, University of Groningen.

Makinen, G., (1986) "The Greek Hyperinflation and Stagnation of 1943-1946", Journal of Economic History, 46: 795-805.

Matsaganis, M., (2011) Social Policy in Hard Times, Athens: Kritiki (in Greek). 
Mauro, P. (1998), Corruption and the composition of government expenditure, Journal of Public Economics, 69, 263-279.

Mavrogordatos, G. T., (1983) Stillborn Republic: Social Coalitions and Party Strategies in Greece, 1922-1936, Berkeley: University of California Press.

Mitrakos, T. and P. Tsakloglou, (2012) "Inequality, Poverty and Material Welfare: From Regime Transition to the Current Crisis" in Bank of Greece (ed), Social Policy and Social Cohesion in Greece under Conditions of Economic Crisis, Athens: Bank of Greece (in Greek).

Moutos, T. and C. Tsitsikas, (2010) "Whither Public Interest: The Case of Greek Public Finances", FinanzArchiv: Public Finance Analysis, 66: 170-206.

OECD (2012), Education at a Glance 2012, OECD, Paris.

Olson, M., (2000) Power and Prosperity: Outgrowing Communist and Capitalist Dictatorships, NY: Basic Books.

Pagoulatos, G., (2003) Greece's New Political Economy: State, Finance and Growth from Postwar to EMU, London: Palgrave.

Pagoulatos, G., (2006) National Bank of Greece 1940-2000, Athens: NBG (in Greek).

Passarelli, F. and G. Tabellini (2013), Emotions and Political Unrest, CESifo Working Paper No. 4165.

Peltzman, S., (1976) "Towards a More General Theory of Regulation", Journal of Law and Economics, 19:211-240.

Pesmatzoglou, S., (1993) "The 1980s in the Looking Glass: PASOK and the Media.", in Richard Clogg (ed.) Greece 1981-89: The Populist Decade, London: Macmillan.

Piketty, T., (1995) "Social Mobility and Redistributive Politics", Quarterly Journal of Economics, 110: 551-584.

Pridam, G. and S. Verney (1991) "The Coalitions of 1989-90 in Greece: Inter-party Relations and Democratic Consolidation", West European Politics, 14: 42-69.

Psacharopoulos, G., and Papakonstantinou, G. (2005) "The Real University Cost in a 'Free' Higher Education Country", Economics of Education Review 24: 103-108.

Schmitter, P. C., (1974) "Still the Century of Corporatism?", in Pike, F. B. and T. Stritch (eds) The new corporatism: Social-political Structures in the Iberian World, Notre Dame, IN: Notre Dame University Press.

Spourdalakis, M., (2008) "2007 Greek elections: signs of major political realignment, challenges and hopes for the left", Studies in Political Economy, 82: 171-186.

Stathakis, G., (2004) Truman Doctrine and Marshall Plan: The History of US Aid in Greece, Athens: Vivliorama (in Greek). 
Stigler, G., (1971) "The Theory of Economic Regulation" Bell Journal of Economics and Management Sciences, 2: 3-21.

Sweet-Escott, B., (1954) Greece: a political and economic survey 1939-1953, Royal Institute of International Affairs.

Tinios, P., (2012) "Greece: Extreme Crisis in a Monolithic Unreformed Pension System", Global Social Policy, 12: 332-344.

Tsakalotos, E., (1998) "The political economy of social democratic economic policies: the PASOK experiment in Greece”, Oxford Review of Economic Policy, 14: 114-138.

Tsoucalas, C., (1987) State, Society, Labour in Postwar Greece, Athens: Themelio (in Greek).

Williamson, O., (1985) The Economic Institutions of Capitalism, New York: Free Press.

Williamson, O., (1996) The Mechanisms of Governance, New York: Oxford University Press. 